\title{
The Analysis of Use of Official Account in the Application of WeChat to Improve Reading Ability of Learning Indonesian as Second Language for Chinese Students
}

\author{
Nan Wang* \\ Indonesian Language and Literature \\ Education of Gradute School \\ Universitas Negeri Yogyakarta \\ Yogyakarta, Indonesia \\ wang0011pasca.2018@student.uny.ac.id
}

\author{
Nurhadi \\ Faculty of Language and Arts \\ Universitas Negeri Yogyakarta \\ Yogyakarta, Indonesia \\ Nurhadi@uny.ac.id
}

\begin{abstract}
With the speedy science and technology development, it has provided us great convenience in language learning. More and more Chinese students study Indonesian language as a second language under the "One Belt, One Road" initiative, but the lack of Indonesian teachers and the students mainly based on textbooks and other printing products create difficulties in learning Indonesian language. The students also always meet the problem in less vocabulary, week grammar and lack of materials in developing Indonesian reading skills. So it not only can breaks through the limitations of time and space, but also provides great help for vocabulary and grammar in improving students' reading ability in Indonesian learning by mobile learning (m-learning). This article will use qualitative research and field investigation research to learn about based on the concepts of Wechat and mobile learning, discuss the factors affecting Indonesian reading ability, the feasibility of using Wechat to improve Indonesian's reading ability, and find out strategies to improve the reading ability in Indoneisan language laearning in the model of self-learning or a combination of language input and output on Wechat.
\end{abstract}

Keywords—mobile learning, Indonesian reading ability, L2, application of mobile technology

\section{INTRODUCTION}

With the rapid development of social economy, it has already entered the internet era. Internet has replaced many traditional ways of delivering information as an information carrier, like magzines, newspapers and paper print. Especially in recent years, with continuous updates and development of mobile technology, information technology has become increasingly popular in the community. Mobile technology realizes the character of obtaining information, which is fast and convenient. The development of information technology not only improves the quality of our lives, like shopping online, humans can get the latest information in real time anywhere, but also expand the way of learning, which is not only to rely on printing products.
In the 21st century, information technology occupies a status of dominance. In addition, multimedia has begun to emerge based on the development of information technology. The development of information technology that is able to process, package, and display, and disseminate learning information both audio, visual, audiovisual and even multimedia (Darmawan, 2014).

The development of information technology has influenced traditional teaching models. It is easier for students to get valid information. Specifically in the area of education and training that the application of communication technology is very supportive to develop an innovation, especially related to: (a) virtual learning; (b) distance learning; (c) mailing and telephone; (d) computer mediated communication; (e) computer based training; (f) E-learning; (g) electronic tutorial (Darmawan, 2014).

In September of 2013, Chinese President Xi Jinping gave a speech at Nazarbayev Astana University during an official visit to Kazakhstan. In his speech, entitled "Promoting Friendship Between Our People and Working Together to Create A Bright Future", the president of China stated that to establish closer economic relations, deepen cooperation and expand space for development in the European region, this is the first time China has presented "One Belt, One Road" initiative throughout the world. Initiative

"One Belt, One Road" also means it is a national strategy for China in cooperation with neighboring countries (Ministry of Foreign Affairs, the People's Republic of China). Neighboring countries mainly refer to Southeast Asia and South Asia. Therefore, among them Indonesia is also one of the participating countries. Under the " One Belt, One Road" initiative, Indonesia or Chinese learning has become an important bridge between the two countries, learning Indonesian has become a warm-up in China. With more and more universities have established Indonesian language majors, more and more students learn Indonesian as a second language (L2). However, 
there are many problems in learning Indonesian, which is lack of Indonesian teachers, the medium of learning is mainly dependent on print media and Indonesia learning media are relying on textbooks. According to Krashen (1985), if we want to master the second language (L2) well, we have to do a lot of language input. A lot of listening and a lot of reading are the necessary means we can take. Reading is very helpful for the accumulation of vocabulary and the acquisition of spelling. A large amount of vocabulary must come from reading rather than remembering vocabulary (Jin \& Yan, 2018).

The survey results through field visits show that even those who have studied Indonesian for more than two years, but they also can't fully understand the local reading materials. They even wrongly thought that the words on the textbook have been able to satisfy their cultivation of reading ability. In the early 1980s a second language learning theory emerged and this theory contained five hypotheses, namely the acquisitionlearning hypothesis, the monitor hypothesis, the natural order hypothesis, the input hypothesis and the affective filter hypothesis (Lewis, 1993). The input hypothesis is the core of monitor theory in Krashen's monitor theory, it is intended that as a second language learner, a higher level of language input than the current level should be performed.

This article will learn the problems in learning Indonesian for Chinese students, the definition of mobile phone learning, discuss the factors affecting Indonesian reading ability, and the feasibility of using Wechat to improve Indonesian's reading ability, and find out strategies to improve the reading ability in Indoneisan language laearning by the model of self-learning or a combination of language input and output on Wechat.

\section{METHODOLOGY}

This research use qualitative research and field investigation research. The method in this research is descriptive method and the author took 11 students from the 2017 Indonesian major of School of Foreign Languages in Qujing Normal University as experimental subjects. Applying the self-learning model and the combination of language input and output to the Indonesian reading course by using the offcial account in Wechat. Experimental subjects are tested twice. Once at the beginning of the second semester, the second time is after 16 weeks of teaching. The experimental group has used the the offcial account in Wechat learning mode for teaching, and the control group hasn't used the traditional teaching mode for teaching. The articles pushed in the Wechat are selected by the teacher based on the students' Indonesian language ability then used in the experimental group. Descriptive research is a method that serves to describe or give a description of the object under study through data or samples that have been collected as they are, without conducting analysis and making general conclusions (Sugiyono, 2011). Descriptive as one of the characteristics of qualitative research to collect data. The data collected is in the form of words, pictures and not numbers. (Moleong, 2017). The data come from interview scripts, field notes, and other official documents. Then data measurement by using SPSS. The author will describe the quotations that are from the object of research and analyze to get reality.

\section{RESEARCH RESULTS AND DISCUSSION}

\section{A. Pr oblems in Chinese Indonesian Learning}

Under China's policy of opening to the outside world, more and more students are interested in studying Indonesian language by the relationship between China and Indonesia is becoming increasingly friendly. But the amount of Indonesian teachers can not fullfil the needs of teaching, the survey results show that Indonesian major was estabished in 2017 in Qujing Normal University and there were just one Chinese - Indonesian teacher and one Indonesian foreign teacher from Yogyakarta State University in Indonesia. There were two Chinese Indonesian teacher and one Indonesian foreign teacher from Yogyakarta State University in Indonesia in the year of 2019 in Yunnan Minzu University. There were two Chinese - Indonesian teacher and two Indonesian foreign teacher from Indonesia in the year of 2019 in Jilin International Studies University. In addition to this, Indonesian learning resources are very limited in China and are mainly based on textbooks, which is Bahasa Indonesia Kuliah Intensif Tingkat Dasar I, II, III dan Buku Pelajaran Percakapan Bahasa Indonesia published by World Book Inc. So students receive a limited amount of vocabulary and materials. Even a small number of students have gradually lost interest in learning Indonesian for a period of time.

\section{B. The Definition of M-learning}

Mobile-learning (M-learning) is considered that students do all forms of learning in places that are not predetermined or use learning opportunities provided by mobile technology (Vavoula, 2005). Mobile learning as a learning strategy in the media era, it has the following characteristics, which breaks the previous learning paradigm and learning thinking, and is extremely attractive to contemporary college students. It not only increases the motivation for college students to learn independently, but also put students in a broader learning environment and learn language with interests (Miao, 2016). Wechat is one of the real-time communication applications developed by Tencent companies in China. Because of the popularity of information technology, more and flexible learning tools, language learners can obtain more individual needs, and use WeChat in language learning to meet the needs of language learning in the information age (Wang, 2015). Official accounts for learning Indonesian are usually edited by Indonesian who studys Mandarin or Chinese who study Indonesian. The official account is used after opening WeChat and clicking on the Official Account option, then selecting an official account related to Indonesia. After that, the 
system will automatically send articles in Indonesian and Mandarin. Not only that, but it will also send Indonesian culture, grammar, tourism and the latest news from Indonesia.

\section{The Factors of Affecting Reading Ability in Indonesian Language Learning}

In Krashen's second language acquisition theory, there are two main factors that influence the reading ability. The first is the affective filter hypothesis which means emotion is the basis for improving reading ability. For students who learn Indonesian, context plays a very important role in learning Indonesian. Construction of reading skills and language learning cannot be separated in interests. In Krashen's SLA theory points out that not a large number of appropriate language inputs allow students to learn a second language, and many emotional factors must be considered (Jin \& Yan, 2018). Students' reading interests and self-confidence are directly proportional to reading ability. Therefore, cultivating students' reading interest and self-confidence is the key to improving reading ability. Personality factors are interrelated with motivational factors. Briefly, it is hypothesized that the self-confident or secure person will be more able to encourage intake and will also have a lower filter (Krashen, 1981).

The second factor that affects students' reading ability is language input. For learners who are learning a second language (L2) for a while, the difficulty of reading materials should be more difficult. For drills that focus on acquisition, even if they manage to hit the target, $i+1$, we may question whether they actually provide enough input for real acquisition to occur (Krashen, 1981). Therefore model $i+1$ emphasized that for the students who have been studying Indonesian for a certain period, caretakers can enhance students' reading ability through some reading materials outside the classroom. Second language learners can only complete the acquisition under the condition of " $i+1$ " after receiving enough language input $(\mathrm{Li}, 2013)$.

\section{The Feasibility of Applying Official Account in WeChat to Indonesian Reading Course}

Based on the above problems, language skills can be achieved through language learning and language acquisition. Technological advances have made computer-assisted language learning (CALL) a broad field that includes the use of the Internet (multimedia sources, online dictionaries) (Long \& Dought, 2009). The author took 11 students from the 2017 Indonesian major of School of Foreign Languages in Qujing Normal University as experimental subjects to conduct a survey. The results show that among the 11 students the mobile phone ownership rate reached $100 \%$.
When building a reading curriculum, you must choose material, resources that are interesting, varied, handsome, abundant, can be easily obtained and used well. Based on these principles can support the next development goal, namely promoting word recognition skills, building a large vocabulary recognition, training comprehensive skills that combine grammar awareness, identification of main ideas, and comprehensive strategies, such as strategic instruction not separate from text understanding instructions and building awareness discourse structure, promoting reading strategies and practicing reading fluency (Long \& Dought, 2009).

In language learning there are three inseparable elements, phonology, vocabulary, syntax. Vocabulary correlates with second language reading comprehension, the relationship between vocabulary and reading skills is very close (Long \& Dought, 2009). Traditional Indonesian teaching has not yet broken through the limitations of traditional education models, and it ignores the experience factor of language use, students often waste a lot of time and energy learning grammar rules and vocabulary knowledge, while the words and grammar rules they learned did not improve their reading ability. However, for students who learn Indonesian in China, the environment in which students can interact with Indonesian is often difficult to find other suitable places other than in the classroom.

Multimedia environment as an environment where the material is presented in more than one format, for example in words and in pictures. In order for meaningful learning to take place in a multimedia environment, learners must learn from five cognitive processes: (1) choosing words that are relevant for processing in verbal working memory, (2) selecting images that are relevant for processing in visual working memory, (3) organizing selected words into verbal mental models, (4) organizing selected images into mental visual models, and (5) combining verbal and visual representations with knowledge preexisting (Richard, 2009).

Any language cannot be separated from the principle of learning. The principles in language learning are contextual principles, integrative principles, functional principles, appreciative principles. In traditional language learning, the teacher acts as a teacher, and students are responsible for listening, so students can understand the theory, but they do not really apply the theory to real activities. Contextual principles are learning concepts that help teachers link material taught with realworld situations and encourage students to make connections between their knowledge and its application in their lives as family and community members (US Department of Education, 2001). Language is a system, language subsystem is phonology, morphology, syntax, and semantics. These four systems cannot stand alone (Maksan, 1994). Functional principles in language learning are essentially in line with the concept of learning a communicative approach. The concept of the communicative approach implies that the teacher is not the ruler in the class. The teacher is not the only provider of information and learning resources. On the contrary, 
the teacher must act as a guide for information (Hairuddin, 2008). Students can master basic knowledge of Indonesian through the use of the official Wechat account, students focus on sentences, phonology, vocabulary, grammar.

Based on the Indoneisan language laearning by the model of self-learning or a combination of language input and output on Wechat, reading articles sent by the official account from WeChat can increase motivation and interest of Chinese students in learning Indonesian. Language learning is a cognitive development process. The method is the integration of cultural factors into Indonesian language learning. A better understanding of Indonesian culture is very beneficial for learning Indonesian. Thus, when learning Indonesian through an official account Wechat can make Chinese students know interesting historical places, customs, ethics, ways of thinking, proverbs, and even intuitively understand Indonesian values even though students are not in Indonesia. The following table shows the analysis of the results for the two reading tests.

TABLE 1. THE RESULT OF READING TEST

\begin{tabular}{|c|c|c|c|c|c|c|}
\hline & \multicolumn{5}{|c|}{ Paired Differences } & \multirow{3}{*}{$\begin{array}{l}\text { Sig. } \\
\text { (2-t } \\
\text { aile } \\
\text { d) }\end{array}$} \\
\hline & \multirow[b]{2}{*}{ Mean } & \multirow{2}{*}{$\begin{array}{c}\text { Std. } \\
\text { Deviati } \\
\text { on } \\
\end{array}$} & \multirow{2}{*}{$\begin{array}{c}\text { Std. } \\
\text { Error } \\
\text { Mean }\end{array}$} & & & \\
\hline & & & & $\mathrm{t}$ & df & \\
\hline \begin{tabular}{l|l} 
Pair & V01- \\
1 & N02
\end{tabular} & -1.72727 & 4.14948 & 1.25112 & -4.989 & 19 & .002 \\
\hline
\end{tabular}

As can be seen from the table above, $\mathrm{P}<0.05$, there is a significant difference between pre-using official account in Wechat and post-using official account in Wechat. So it can be proven that using official account in

\section{REFERENCES}

Deni Darmawan. ( 2014 ). Inovasi Pendidikan Pendekatan Praktik Teknologi Multimedia dan Pembelajaran Online. Bandung: PT Remaja rosdakarya.

Hairudin, dkk. (2008). Bahan Ajar Cetak Pembelajaran Bahasa Indonesia. Jakarta: Dirjen pendidikan tinggi departemen pendidikan nasioanl.

Jin, Guiqing. \& Yan Qiong. (2018). A Study of the Application of Second Language Acquisition Theory to English Reading Ability. CNKI, Volume 16, Nomor 1, February 2018.

Stephen, D,Krahen. (1981). Second Language Acquisition and Second Language Learning.

University of Southern California: Pergamon Press Inc

Lexy J. Moleong. (2017). Metodologi Penelitian Kualitatif. Bandung: PT Remaja Rosdakarya Offset.

Lewis M. (1993). The Lexical Approach: The State of ELT and a Way Forward. England:Language Teaching Publication.

Li Yufeng. (2013). Dissemination and Optimization of University Moral Education Information Based on WeChat. CNKI, Volume 133, Nomor 4, September 2013

Michael H. Long., \& Catherine J. Doughty. (2009). The Handbook of

Language Teaching. Chichester: Blackwell Publishing Ltd.
Wechat for Indonesian reading ability training is indeed effective. It also menas it is feasible and can achieve good results by using official account in Wechat in improving reading ability of Indonesian language.

There are two main application modes of mobile learning for Indonesian reading ability in WeChat, namely the combination of language input and language output and the self-learning. Based on the two model above, the student should improve autonomous learning ability and the teachers also should redefine their role in teaching.

\section{CONCLUSION}

With the rapid development of information technology and under the "One Belt, One Road

" initiative, learning Indonesian language as a second langguage has become a warm-up in China.

There are many problems in Chinese-Indonesian learning like the lack of Indonesian teachers, Indonesian learning resources are very limited, some students lost the interests for a certain peroid. But it is proved that using official account in Wechat for Indonesian reading ability training is indeed effective and can achieve good results.

On the basis of Krashen's theory of second language (L2) acquisition and interaction with teachers and students, use the mode of self-learning and language input and language output to strengthen students' reading ability and reflect the characteristics of mobile learning.

Maksan, Marjusman. (1994). Ilmu Bahasa. Padang:

IKIP Padang Press.

Miao Ning. (2016). English Mobile Learning Strategies in Universities and Colleges Based on WeChat. CNKI, Volume 136, Nomor 5, March 2016.

Richard E. Mayer. (2009). Multimedia Learning Prinsip-prinsip dan Aplikasi. Yogyakarta: Pustaka pelajar.

Sugiyono. (2011). Metode Penelitian Kuantitatif, Kualitatif dan $R \& D$. Bandung: Afabeta.

Tang, Xujun. (2015). Laporan Pengembangan Media Baru Tiongkok-Buku Biru Media Baru - No. 6. Beijing: Pusat Penerbitan Sastra Ilmu Sosial.

U.S. Department of Education. (2001). The condition of education 2001. Washington: Government Printing Office.

Vavoula, G. N. (2005). D4.4: A Study of Mobile Learning Practices: Internal report of MOBIlearn project.

Wang, Zhuoyu. (2015). Penelitian Platform WeChat dalam Pembelajaran Bahasa. Penelitian pendidikan terbuka. CNKI, Volume 21, Nomor 2, 2015.

https://www.fmprc.gov.cn/mfa_eng/topics_665678/xj pfwzysiesgjtfhshzzfh_665686/t1076334.shtml 